\title{
SEVERE ACUTE RESPIRATORY SYNDROME CORONAVIRUS-2 ANTIGENS AND ANTIBODIES IN BREAST MILK
}

\author{
ANNE SÜTÜNDE SARS-COV-2 ANTIJENI VE ANTIKORU
}

\author{
Gonca KESKINDEMIRCi ${ }^{1,2}$ (D), Nalan KARABAYIR ${ }^{3}$ (D), Ayşe iSTANBULLU TOSUN ${ }^{4}$ (D), Selda HANÇERLi TÖRÜN ${ }^{5}$ (D),

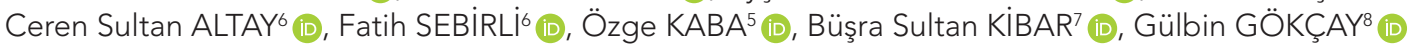 \\ IIstanbul University, İstanbul Faculty of Medicine, Department of Pediatrics, Division of Social Pediatrics, Istanbul, Turkey \\ ${ }^{2}$ Istanbul University, Health Science Institute Child Health Institute, Social Pediatrics PhD Program, Istanbul, Turkey \\ ${ }^{3}$ Istanbul Medipol University, International School of Medicine, Department of Pediatrics, Division of Social Pediatrics, Istanbul, Turkey \\ ${ }^{4}$ Istanbul Medipol University, Faculty of Medicine, Department of Microbiology, Istanbul, Turkey \\ ${ }^{5}$ Istanbul University İstanbul Faculty of Medicine, Department of Pediatrics, Division of Child Infection Diseases, Istanbul, Turkey \\ 'istanbul Medipol University, Faculty of Medicine, Department of Pediatrics, Istanbul, Turkey \\ ${ }^{7}$ Yalova Goverment Hospital, Kocaeli, Turkey \\ ${ }^{8}$ istanbul University, Child Health Insitute, Department of Social Pediatrics, Istanbul, Turkey
}

ORCID IDs of the authors: G.K. 0000-0003-1797-2802; N.K. 0000-0002-8003-1952; A.I.T. 0000-0003-3952-1914; S.H.T. 0000-0002-3216-2413; C.S.A. 0000-0002-5439-192X; F.S. 0000-0001-6465-0449; Ö.K. 0000-0002-8381-3255; B.S.K. 0000-0002-6535-1034; G.G. 0000-0003-1042-0407

Cite this article as: Keskindemirci G, Karabayir N, Istanbullu Tosun A, Hancerli Torun S, Altay CS, Sebirli F, et al. Severe acute respiratory syndrome coronavirus-2 antigens and antibodies in breast milk. J Ist Faculty Med 2021;84(3):287-92. doi: 10.26650/IUITFD.2021.928835

\section{ABSTRACT}

Objective: This study aimed to determine the presence of severe acute respiratory syndrome coronavirus-2 (SARS-CoV-2) antigens and IgM and IgG antibodies in breast milk of mothers diagnosed with Coronavirus disease-19 (COVID-19).

Methods: The study was conducted in 11 mother-child pairs. Breastfeeding mothers who were either positive according to a PCR test or those who were negative but had COVID symptoms were included in the study. Expressed milk was stored at $-20 /-80^{\circ} \mathrm{C}$ until analysis. Breastmilk SARS-CoV-2 antigens and IgM and IgG antibodies were measured. The infants were followed for at least 15 days.

Results: SARS-CoV-2 PCR tests using a nasopharyngeal swab was positive in 10 of 11 mothers. Nine mothers had symptoms of COVID-19. Breast milk samples were taken, on average, 15 days after symptom onset or a positive PCR result. SARS-CoV-2 PCR tests using a nasopharyngeal swab was positive in seven infants. The SARS-CoV-2 antigen was not detected in the breast milk of any of the mothers. However, SARS-CoV-2 IgG and IgM antibodies were detected in the breast milk of two mothers, who had a positive PCR test and experienced clinical symptoms. The children of these two mothers experienced no symptoms.

\section{ÖZET}

Amaç: Koronavirüs hastalığı-19 (COVID-19) tanısı almış annelerin anne sütünde Şiddetli Akut Solunum Sendromu koronavirüs-2 (SARS-CoV-2) antijeni ile IgM ve IgG antikorlarının belirlenmesi amaçlanmıştır.

Gereç ve Yöntem: Çalışma 11 anne-çocuk çifti ile gerçekleştirildi. Çalışmaya PCR testine göre pozitif olan veya negatif olup ancak COVID semptomları olan emziren anneler dahil edildi. Sağılmış anne sütü, analiz aşamasına kadar $-20 /-80^{\circ} \mathrm{C}$ 'de saklandı. Anne sütü SARS-CoV-2 antijeni ve IgM ve IgG antikorları ölçüldü. Bebekler en az 15 gün takip edildi.

Bulgular: Nazofarengeal sürüntüde SARS-CoV-2 PCR testleri 11 annenin 10'unda pozitifti. Dokuz annede COVID-19 semptomları vardı. Annelerin semptomlarından veya pozitif PCR sonuçlarından ortalama 15 gün sonra anne sütü örneği alındı. Nazofarengeal sürüntü testlerinde SARS-CoV-2 PCR testleri 11 anne bebeğinin 7'sinde pozitifti. SARS-CoV-2 antijeni hiçbir annenin anne sütünde saptanmadı. Ancak PCR testi pozitif olan ve klinik semptomlar yaşayan iki annenin sütünde SARS-CoV-2 IgG ve IgM antikorları tespit edildi. Bu iki annenin çocukları hiçbir belirti göstermedi.

Corresponding author/iletişim kurulacak yazar: keskindemirci@hotmail.com

Submitted/Başvuru: 28.04.2021 • Accepted/Kabul: 09.05.2021 • Published Online/Online Yayın: 17.05.2021 
Conclusion: Official institutions have recommended and supported breastfeeding during the SARS-CoV-2 pandemic. Our findings support this recommendation. The promotion and protection of breastfeeding under emergency conditions is of great importance for the health of children, mothers, and society.

Keywords: Breast milk, COVID-19, breastfeeding
Sonuç: SARS-CoV-2 salgınında resmi kurumlar tarafından emzirme tavsiye edilmiş ve desteklenmiştir. Bulgularımız bu öneriyi desteklemektedir. Emzirmenin acil koşullarda teşviki ve korunması, çocuğun, annenin ve toplumun sağlığı açısından çok önemlidir.

Anahtar Kelimeler: Anne sütü, COVID-19, emzirme

\section{INTRODUCTION}

Coronavirus disease-19 (COVID-19) is caused by a severe acute respiratory syndrome coronavirus-2 (SARS-CoV-2), which first emerged in China in December 2019, and was declared as a pandemic by the World Health Organization (WHO) in March $2020(1,2)$. The disease has been reported to be mild in children (3). At the start of the pandemic, a negative opinion on breastfeeding was reported by a group of experts in China (4). Nevertheless, the importance of continuing breastfeeding was emphasized by official institutions dealing with child health, and breastfeeding has continued to be promoted during the COVID-19 pandemic (5). Current information suggests that the virus is transmitted via respiratory droplets (6). There is currently no study that has reported transmission via breast milk, and the WHO has highlighted that active COVID-19 transmission through breast milk has not been demonstrated (7). Given the short- and longterm benefits of breastfeeding for the mother and child, the well-documented antimicrobial properties and immune-enhancing structure of breast milk, the epidemiological data on respiratory viruses (e.g., SARS-CoV-2, Middle East respiratory syndrome coronavirus, and influenza), and evaluations based on recent publications, it is important to protect and maintain breastfeeding during the epidemic $(8,9)$.

In this study, we aimed to investigate the presence of virus antigens and immunoglobulin $\mathrm{M}(\mathrm{IgM})$ and immunoglobulin-G (lgG) antibodies against SARS-CoV-2 in breast milk of mothers diagnosed with COVID-19. Our findings will contribute to the development of national and global evidence-based guidelines and provide valuable epidemiological data.

\section{MATERIAL AND METHOD}

This cross-sectional, descriptive study was conducted in Istanbul University Istanbul Faculty of Medicine and Istanbul Medipol University International School of Medicine between June 15, 2020 and August 30, 2020. Lactating mothers who tested positive for SARS-CoV-2 using a nasopharyngeal swabs (NS) polymerase chain reaction (PCR) test, who were symptomatic or asymptomatic and had received or were receiving treatment, and those who had COVID-19-like symptoms but tested negative for SARS-CoV-2 based on a NS PCR test and had received or were receiving treatment were included in the study.
Mothers were given specific instructions on how to express milk. They were asked to wash their hands for at least 20 seconds and clean their breasts with water and soap before expression. Milk stream was initiated by manual expression, and approximately the first $3 \mathrm{~mL}$ were discarded to obtain a midstream breast milk sample (10). At least $10 \mathrm{~mL}$ of milk was obtained and stored in milk storage sterile containers. Breast milk samples were stored at $-20^{\circ} \mathrm{C}$ or below until analysis.

Mode of delivery, mothers' SARS-CoV-2 NS PCR test results, mothers' clinical symptoms, treatment received for COVID-19, day milk expressed after diagnosis, childrens' age, children's NS PCR results, children's symptoms, presence of SARS-CoV-2 antigen in breast milk, presence of SARS-CoV-2 lgM and lgG antibodies in breast milk, and follow-up period after milk supply were recorded. The infants of the mothers, whose breast milk samples were collected within the first 15 days of diagnosis, were followed for at least 15 days. Retrospective information was collected on the children of the mothers, who had recovered or completed treatment.

The stored breast milk samples were thawed at room temperature and analyzed for the presence of SARSCoV-2 antigens using COVID-19 Ag FIA (Standard F-Sd Biosensor, Republic of Korea; fluorescent immunoassay to detect SARS-CoV-2) and SARS-CoV-2 antibodies using COVID-19 lgM/lgG Combo FIA (Standart F-Sd Biosensor, Republic of Korea).

The study was approved by the ethics committee of Medipol University (Date: 10.16.2020, No: 457), and the Turkish Ministry of Health was informed. All mothers gave informed consent to participate in the study. The study was supported by Savaş Medical Company.

\section{RESULTS}

The study was carried in 11 child-mother pairs. NS PCR tests showed that 10 of the 11 mothers were positive for SARS-CoV-2, and nine mothers had symptoms. Eight infants were born by cesarean section and three were born by spontaneous vaginal delivery. Three of the 11 mothers were not receiving or had not received any treatment for COVID-19, four had completed treatment, and four were still receiving treatment. Seven mothers had received only hydroxychloroquine as treatment, and one was receiving hydroxychloroquine and lopinavir-ritonavir treat- 


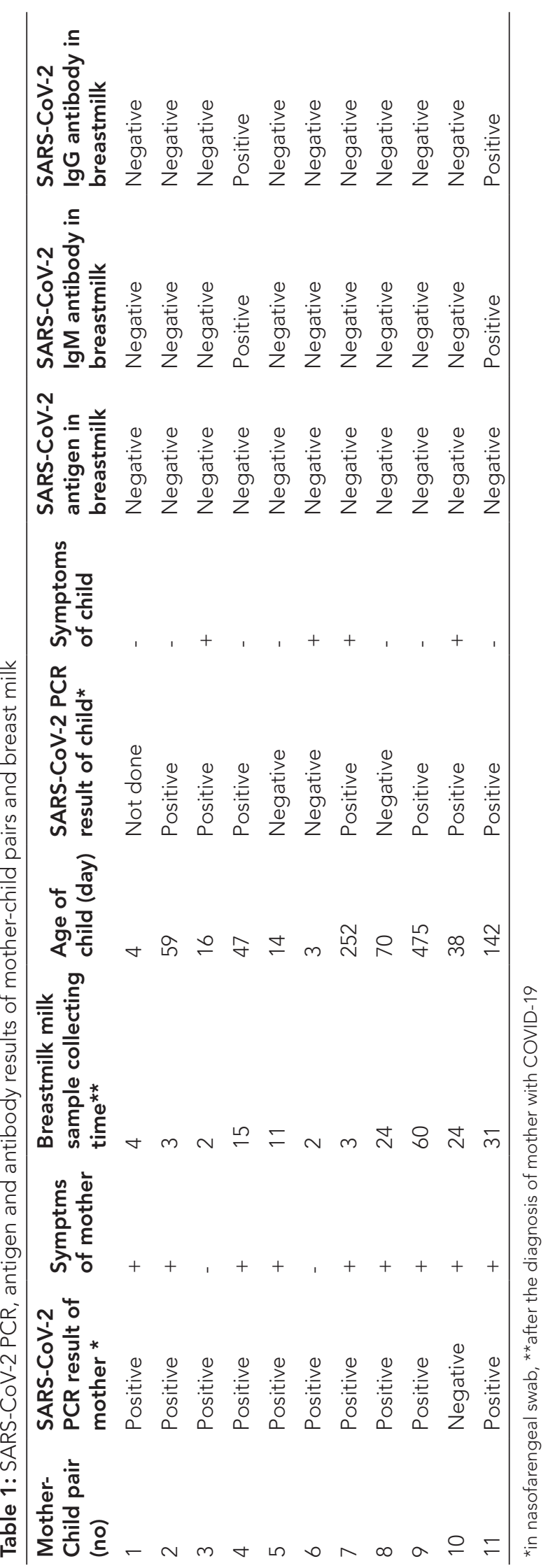

ment. Breast milk samples were collected, on median, 11 days (range 2-60 days) after diagnosis of COVID-19. Samples were collected within the first 15 days of the disease in seven mothers (five samples were collected in the first five days). Infants $(n=7)$ were followed up for at least 15 days. Retrospective information about the history of the children $(n=4)$, whose mothers had recovered or completed treatment, were collected. The median age of children was 47 days (range 3-475 days). NS PCR tests showed that seven children were positive for SARSCoV-2. Four had symptoms and two were hospitalized and received treatment. SARS-CoV-2 antigens were not identified in the breast milk of any of the mothers. SARSCoV-2 IgM and IgG antibodies were positive in milk samples of two mothers. All children were breastfed throughout the study period. Findings are summarized in Table 1.

Mother-child pair 1: The NS PCR test showed the mother was positive for SARS-CoV-2, and she displayed COVID-19 symptoms. The infant had no symptoms. The breast milk sample was collected four days after the mother was diagnosed with COVID-19. The infant was followed up for one month. No additional problems were observed during the follow-up period. There were no other cases with a positive PCR test in the household.

Mother-child pair 2: The NS PCR test showed the mother was positive for SARS-CoV-2, and she displayed COVID-19 symptoms. The NS PCR test result of the infant was also positive, but they showed no symptoms. The breast milk sample was collected three days after the mother was diagnosed with COVID-19. The grandparents in the same household both tested positive for SARS-CoV-2 following a PCR test. The infant was followed up for 15 days and no additional problems were observed during the follow-up period

Mother-child pair 3: The NS PCR test showed the mother was positive for SARS-CoV-2, but she showed no COVID-19 symptoms. The NS PCR test result of the infant was also positive and he experienced fever. The breast milk sample was collected two days after the mother was diagnosed with COVID-19. The child was hospitalized in the neonatal intensive care unit for 10 days and received antibiotics for sepsis. The father and brother also tested positive for SARS-CoV-2. The infant was discharged from hospital after 15 days and made a full recovery.

Mother-child pair 4: The NS PCR test showed the mother was positive for SARS-CoV-2, and she displayed COVID-19 symptoms. The NS PCR test results of the infant were also positive but showed no symptoms. The child was followed up in the hospital without treatment. The breast milk sample was collected 15 days after the mother was diagnosed with COVID-19. Although antigens were not detected, SARS-CoV-2 IgG and IgM antibodies were present in the breast milk. The father and 
two brothers in the same household had positive PCR test results. The infant was followed up for 45 days and had no problems during the follow-up period.

Mother-child pair 5: The NS PCR test showed the mother was positive for SARS-CoV-2, and she displayed COVID-19 symptoms. The NS PCR test showed the infant was negative, and they showed no symptoms. The breast milk sample was collected 11 days after the mother was diagnosed with COVID-19. The father in the same household tested positive for SARS-CoV-2. The infant was followed up for 15 days and no problems were observed during the follow-up period.

Mother-child pair 6: The NS PCR test showed the mother was positive for SARS-CoV-2, but she showed no COVID-19 symptoms. The NS PCR test results of the infant were negative for SARS-CoV-2 but was kept under observation for suspected fever. Because no fever was observed during follow-up and acute phase reactants were negative, the infant was discharged without treatment. The breast milk sample was collected two days after the mother was diagnosed with COVID-19. The father in the same household tested positive for SARS-CoV-2. The infant was followed up for one month and no additional problems were observed during the follow-up period.

Mother-child pair 7: The NS PCR test showed the mother was positive for SARS-CoV-2, and she experienced COVID-19 symptoms. The NS PCR test result of the infant was also positive for SARS-CoV-2 PCR and was kept under observation without treatment, but no fever was detected. The breast milk sample was collected three days after the mother's COVID-19 diagnosis. The father and grandmother in the same household were index cases who had positive PCR tests. The infant was followed up for 15 days and no problems were observed during the follow-up period.

Mother-child pair 8: The NS PCR test showed the mother was positive for SARS-CoV-2, and she displayed COVID-19 symptoms. The NS PCR test result of the infant was negative and they showed no symptoms. The father and grandmother in the same household also tested positive for SARS-CoV-2. The breast milk sample was collected 24 days after the mother was diagnosed with COVID-19. Based on history of the infant, no problems developed.

Mother-child pair 9: The NS PCR test showed the mother was positive for SARS-CoV-2, and she showed COVID-19 symptoms. The NS PCR test result of the child was positive, but the child had no symptoms. The father in the same household was an index case who had a positive PCR test result. The breast milk sample was collected 60 days after the mother's COVID-19 diagnosis. The history of the child indicated no problems.
Mother-child pair 10: The NS PCR test showed the mother was negative for SARS-CoV-2, but she experienced COVID-19 symptoms. The infant was hospitalized for 10 days in the newborn intensive care unit because of a positive NS PCR test result and fever and was discharged on day 14 and made a full recovery. The aunt and cousin in the same household both tested positive for SARS-CoV-2. The breast milk sample was collected 24 days after the mother's COVID-19 diagnosis. The history of infant indicated no additional problems following discharge from the hospital.

Mother-child pair 11: The NS PCR test showed the mother was positive for SARS-CoV-2, and she displayed COVID-19 symptoms. The NS PCR test results of the infant were positive, no symptom was observed. The breast milk sample was collected 31 days after the mother's COVID-19 diagnosis. Although antigens were not present, SARS-CoV-2 IgG and IgM antibodies were detected in the breast milk. The father and brother in the same household tested positive for SARS-CoV-2. The history of the child indicated no additional problems.

\section{DISCUSSION}

Our study investigated the breast milk and breastfed children of mothers who have been followed with the diagnosis of COVID-19. Using a rapid antigen test, no SARS-CoV-2 antigens were identified in breast milk samples of mothers who tested positive for SARS-CoV-2 or who tested negative for SARS-CoV-2 but experienced clinical symptoms. However, SARS-CoV-2 IgG and IgM antibodies were both detected in two breast milk samples. All mothers continued to breastfeed their babies despite testing positive for SARS-CoV-2 or having symptoms (in those with a negative PCR test result). This is the first study investigating SARS-CoV-2 in breast milk using a rapid antigen test.

The antiinfection properties of breast milk have been reemphasized by our findings. Antibodies (particularly secretory IgA), soluble components, cellular components, and bioactive factors, such as microorganisms, have an important role in the antiinfection properties of breast milk (10). Chan et al. also suggested that lactoferrin found in breast milk has a protective effect against COVID-19 (11).

In a study on the transmission of the virus via breast milk, a nucleic acid test of breast milk showed a positive presence of the virus, though contamination could not be ruled out (12). In our study, measures were taken to prevent contamination. The virus was not identified in the breast milk of any of the mothers despite 10 of 11 mothers testing positive for SARS-CoV-2, which demonstrated that the virus is not transmitted by breast milk. 
In our study, the presence of SARS-CoV-2 in breast milk was investigated using a rapid antigen test. There are currently two different diagnostic tests for SARS-CoV-2: molecular and antigen tests. Genetic material is detected by molecular tests, which are known as PCR tests. The process takes several hours to several days to obtain results. In contrast, antigen tests detect specific proteins belonging to the virus and produce results in less than an hour. Although PCR tests are specific and sensitive, antigen tests have been reported to perform best in cases with a high viral load and within five days from symptom onset. Moreover, they are less sensitive compared to molecular tests but their specificity is high. Rapid antigen tests are easy to use, economical, and faster at obtaining results (13-15). In our study, five of the 11 mothers' breast milk samples were collected in the first five days after diagnosis, and of these, three had symptoms. Although milk was obtained earlier in five mothers, no antigens were detected. In previous studies, PCR tests have been used to determine the presence of SARS-CoV-2 virus in breast milk. To the best of our knowledge, this is the first study to investigate the presence of SARS-CoV-2 in breast milk using an antigen test.

Although no SARS-CoV-2 antigens were identified in any of the breast milk samples, SARS-CoV-2 antibodies were positive in two breast milk samples. In a study by Demers-Mathieu et al. antibodies against SARS-CoV-2 S1 and S2 subunits and nucleocapsid were detected in breast milk, and the authors emphasized that these antibodies would protect the child (16). In a study by Gao et al. that involved 14 mothers who had received treatment for COVID-19 and had recovered without sequelae, no nucleic acid belonging to SARS-CoV-2 was identified in their breast milk, and neutralizing antibodies targeting SARS-CoV-2 were observed in the breast milk of three mothers (17). In addition, Dong et al. reported the presence of $\lg G$ and $\lg A$ antibodies but no SARS-CoV-2 detection in the breast milk of a mother (18). Deeks et al. reported that lgG, IgM, and IgA antibody positivity in breast milk had low sensitivity in the first week following the onset of COVID-19 symptoms in mothers, whereas sensitivity gradually increased in the second week and reached the highest level in the third week. They showed that the probability of detecting $\lg \mathrm{M}$ and $\lg \mathrm{G}$ antibodies together was $30.1 \%$ on days $1-7$, $72.2 \%$ on days $8-14$, and $91.4 \%$ on days $15-21$ (19). In our study, breast milk samples were collected on median, 11 days following the onset of symptoms. We speculate that the identification of antibodies in the two breast milk samples was associated with the time of sample collection.

The mothers participating in the study were informed about the continuation of breastfeeding in light of official recommendations and epidemiological data, and continuation of breastfeeding was ensured under preventive measures, and no problems were observed. Our findings support the recommendation that women infected with COVID-19 should be encouraged to continue breastfeeding, given the evidence for the protective effects of breastfeeding on the health of the mother and child.

In our study, eight mothers had received or were receiving treatment for COVID-19. Mothers receiving treatment for COVID-19 were informed that current treatment did not pose an obstacle for breastfeeding in light of scientific data, and all continued to breastfeed (20).

The absence of a control group in our study is a limitation. However, our aim was to evaluate the presence of the virus in the breast milk of infected mothers and examine the effect on children. The low sample size, the use of an antigen test with low sensitivity, and not investigating IgA antibodies are also limitations. Nevertheless, our findings provide important contributions regarding the epidemiology of SARS-CoV-2 in breast milk.

In conclusion, our results indicated that there is no virus transmission via breast milk, and no problems were observed among children who had been breastfed by mothers who were diagnosed with COVID-19. As stated by the WHO, United Nations Children's Fund, and numerous other official health organizations in Turkey, breastfeeding should be maintained and encouraged even under extraordinary conditions, given the short- and long-term benefits for the mother and child.

Ethics Committee Approval: This study was approved by the Istanbul Medipol University, Non-Interventional Clinical Research Ethics Committee (Date:10.06.2020, No:457).

Informed Consent: Written consent was obtained from the participants.

Peer Review: Externally peer-reviewed.

Author Contributions: Conception/Design of Study- G.K., G.G., N.K., A.I.T., S.H.T.; Data Acquisition- G.K., N.K., C.S.A., F.S., Ö.K., B.S.K.; Data Analysis/Interpretation- G.K., G.G., N.K., A.I.T.; Drafting Manuscript- G.K., N.K., G.G.; Critical Revision of ManuscriptG.K., N.K., G.G., S.H.T., A.I.T.; Final Approval and AccountabilityG.K., N.K., A.I.T., S.H.T., C.S.A., F.S., Ö.K., B.S.K., G.G.

Conflict of Interest: Authors declared no conflict of interest.

Financial Disclosure: The study was supported by Savaş Medical Company.

Etik Komite Onayı: Bu çalışma için etik komite onayı İstanbul Medipol Üniversitesi, Girişimsel Olmayan Klinik Araştırmalar Etik Kurulu'ndan alınmıştır (Tarih:10.06.2020, No:457).

Bilgilendirilmiş Onam: Katılımcılardan bilgilendirilmiş onam alınmıştır. 
Hakem Değerlendirmesi: Dış bağımsız.

Yazar Katkıları: Çalışma Konsepti/Tasarım- G.K., G.G., N.K., A.I.T., S.H.T.; Veri Toplama- G.K., N.K., C.S.A., F.S., Ö.K., B.S.K.; Veri Analizi/Yorumlama- G.K., G.G., N.K., A.I.T.; Yazı TaslağıG.K., N.K., G.G.; İçeriğin Eleştirel İncelemesi- G.K., N.K., G.G., S.H.T., A.I.T.; Son Onay ve Sorumluluk- G.K., N.K., A.I.T., S.H.T., C.S.A., F.S., Ö.K., B.S.K., G.G.

Çıkar Çatışması: Yazarlar çıkar çatışması beyan etmemişlerdir.

Finansal Destek: Çalışma Savaş Medikal A.Ş tarafından desteklenmiştir.

\section{REFERENCES}

1. Wu Z, McGoogan JM. Characteristics of and Important Lessons From the Coronavirus Disease 2019 (COVID-19) Outbreak in China: Summary of a Report of 72314 Cases From the Chinese Center for Disease Control and Prevention. JAMA 2020;323(13):1239-42. [CrossRef]

2. WHO Director-General's opening remarks at the media briefing on COVID-19 - 11 March 2020. Available at: https:// www. who.int/dg/speeches/detail/who-director-general-sopeningremarks-at-the-media-briefing-on-covid-19---11- march-2020

3. Children in Coronavirus in children. Available at https:// www.nhs.uk/conditions/coronavirus-covid-19/symptoms/ coronavirus-in-children/. Last accessed date: 25.11.2020

4. Wang L, Shi Y, Xiao T, Fu J, Feng X, Mu D, et al. Chinese expert consensus on the perinatal and neonatal management for the prevention and control of the 2019 novel coronavirus infection. Annals of Translational Medicine 2020;8(3):47. [CrossRef]

5. World Health Organization Q\&A on COVID-19, pregnancy, childbirth and breastfeeding.World Health Organization. Geneva Available at: https://www.who.int/news-room/qa-detail/q-a-on-covid-19-pregnancy-childbirth-andbreastfeeding. Last accessed: date: 25.11.2020.

6. Coronavirus disease (COVID-19): How is it transmitted? How does COVID-19 spread between people Available at: www.who.int/coronavirus/spread. Last accessed date: 26.11.2020.

7. World Health Organisation. Coronavirus disease (COVID-19): Pregnancy and childbirth. Available at: https:// www.who.int/news-room/q-a-detail/coronavirus-diseasecovid-19-pregnancy-and-childbirth

8. World Health Organisation. Rapid advice note on home care for patients with Middle East respiratory syndrome coronavirus (MERS-CoV) infection presenting with mild symptoms and management of contacts. Available at: https://www.who.int/csr/disease/coronavirus_infections/ MERS_home_care.pdf?ua. Last accessed dat: 09.12.2020.
9. Lubbe W, Botha E, Niela-Vilen H, Reimers P. Breastfeeding during the COVID-19 pandemic - a literature review for clinical practice. Int Breastfeed J 2020;15(1):82. [CrossRef]

10. Lawrence RA., \& Lawrence, R. M. Breastfeeding. A Guide For the Medical Profession. Eighth Editionl. Elsevier Health Sciences. 2016, Philadelphia, USA p:573

11. Chang R, Zen Sun W, \& Bun Ng T. Lactoferrin as potential preventative and treatment for COVID-19. International Journal of Antimicrobial Agents 2020;56(3):106118. [CrossRef]

12. Tam PCK, Ly KM, Kernich ML, Spurrier N, Lawrence D, Gordon DL, Tucker EC. Detectable severe acute respiratory syndrome coronavirus 2 (SARS-CoV-2) in human breast milk of a mildly symptomatic patient with coronavirus disease 2019 (COVID-19). Clin Infect Dis. 2020 May 30:ciaa673. doi: 10.1093/cid/ciaa673. [CrossRef]

13. Food and Drug Administration. A Closer Look at Coronavirus Disease 2019 (COVID-19) Diagnostic Testing. Available at: https://www.fda.gov/media/143737/download. Last accessed date: 14.12.2020.

14. Options for the use of rapid antigen tests for COVID-19 in the EU/EEA and the UK.Available at: https://www.ecdc. europa.eu/sites/default/files/documents/Options-use-ofrapid-antigen-tests-for-COVID-19.pdf. Last accessed date: 14.12.2020.

15. Center for Disease Conrtol and Prevention. Coronavirus Disease 2019 (COVID-19) Interim Guidance for Antigen Testing for SARS-CoV-2 Available at: https://www.cdc. gov/coronavirus/2019-ncov/lab/resources/antigen-testsguidelines.html\#table1. Last accessed date: 14.12.2020.

16. Demers-Mathieu V, Do DM, Mathijssen GB, Sela DA, Seppo $A$, Järvinen KM, et al. Difference in levels of SARS-CoV-2 S1 and S2 subunits- and nucleocapsid protein-reactive SlgM/lgM, IgG and SlgA/lgA antibodies in human milk. J Perinatol. 2020:1-10. [CrossRef]

17. Gao X, Wang S, Zeng W, Chen S, Wu J, Lin X, et al. Clinical and immunologic features among COVID-19-affected mother-infant pairs: antibodies to SARS-CoV-2 detected in breast milk. New Microbes New Infect 2020;37:100752. [CrossRef]

18. Dong $Y$, Chi $X$, Hai $H$, Sun $L$, Zhang $M$, Xie WF, et al. Antibodies in the breast milk of a maternal woman with COVID-19. Emerg Microbes Infect 2020;9(1):1467-9. [CrossRef]

19. Deeks JJ, Dinnes J, Takwoingi Y, Davenport C, Spijker R, Taylor-Phillips S, et al. Cochrane COVID-19 Diagnostic Test Accuracy Group. Antibody tests for identification of current and past infection with SARS-CoV-2. Cochrane Database Syst Rev 2020;6(6):CD013652. [CrossRef]

20. Drugs and Lactation Database (LactMed). Available at: https://www.ncbi.nlm.nih.gov/books/NBK501541/ 